\title{
GRUBBING OUT THE FÜHRERBUNKER: RUINATION, DEMOLITION AND BERLIN'S DIFFICULT SUBTERRANEAN HERITAGE
}

\section{Luke Bennett $\mathbb{C}$}

Department of the Natural \& Built Environment

Sheffield Hallam University

Norfolk 306, Howard St, Sheffield, S1 1WB: United Kingdom

e-mail: I.e.bennett@shu.ac.uk

\begin{abstract}
This article presents a case study examining the slow-death of the Berlin Führerbunker since 1945. Its seventy year longitudinal perspective shows how processes of ruination, demolition and urban renewal in central Berlin have been affected by materially and politically awkward relict Nazi subterranean structures. Despite now being a buried pile of rubble, the Führerbunker's continued resonance is shown to be the product of a heterogeneous range of influences, spanning wartime concrete bunkers' formidable material resistance, their affective affordances and evolving cultural attitudes towards ruins, demolition, memory, memorialisation, tourism and real estate in the German capital.
\end{abstract}

\section{Key words}

ruin $\bullet$ demolition $\bullet$ bunkers $\bullet$ subterranean $\cdot$ Berlin $\bullet$ nazism $\bullet$ heritage $\bullet$ materiality

\section{Introduction}

On 30th April 1945 Adolf Hitler committed suicide in the Führerbunker, a reinforced concrete structure buried 8.5 metres beneath the ministerial gardens flanking the Reich Chancellery in central Berlin. The final days leading up to Hitler's death have been the subject of countless books, films and ruminations and will not be restated here. Instead this article will explore the far less well-known story of the subsequent, slow-death of the Führerbunker itself, a story that can provide valuable insights into the ways in which processes of ruination, demolition and urban renewal are affected by materially and politically awkward relict subterranean structures. The analysis will be developed by weaving together glimpses of the Führerbunker in studies of Berlin's urban memory and memorialisation (Ladd 1997; Huyssen 2003; Till 2005; Jordan 2006) with Bartolini's (2015) recent interpretation of the immutable materialities of a fascist era underground concrete bunker in Rome. 
By following the fate of the bunker site from 1945 through to the present day, this article addresses calls for rich case study examination of both processes of ruination and of the recalcitrant, affective-material political geographies of subterranean structures.

First, as regards the particularities of the political geographies of the subterranean, Adey (2013: 53) has called for investigation of the 'intense intimacies' to be found in the underground spaces to which state power retreats in extremis. Klinke's (2018) recent investigation of the Cold War history of the West German Government's nuclear bunker at Marienthal has done much to explicate the materialisation (and claustrophobia) of place, bodies and exterminatory projects entwined in the 'depths of power' (Elden 2013) of an underground command bunker during its operational life, but his study says comparatively little about the effect of those influences upon the bunker's after-life. In noting the limits of his own points of focus, Klinke acknowledges and defers to the recent rise of a body of scholarship concerned with the interplay of matter, affect and meaning-making within abandoned, post-war military and governmental Cold War bunkers (e.g. Bennett 2017a). But abandoned Nazi-era bunkers (ruined or otherwise) have been a notably rarer subject of study (c.f. Virilio 1994; Bennett 2011; Tzalmona 2011). This article therefore seeks to address this deficit by examining the lingering, awkward political valence of the ruins of the most iconic Nazi era subterranean bunker - the Führerbunker - following its abandonment, and the various neverquite-successful attempts made after 1945 to extinguish its feared affective-material and political potency.

Secondly, as regards contributing to the analysis of ruination, this article's narrative, case study-based approach responds to Cairns \& Jacobs' (2014) call for examination of how buildings die. Furthermore it also responds to DeSilvey \& Edensor's (2013) call for more studies of ruination as a process, for they argue that contemporary ruin studies tend to focus on how ruins come to be engaged with (as heritage or otherwise) in the present, with the ruin then treated as a 'given', leaving unexamined the processual questions of 'how' and 'why' the ruin has arisen. This dominant approach is shaped by critical heritage studies' argument (e.g. Smith 2006; Harrison 2013) that heritage is a social construct, formed and reformed in the present appropriating the remains (material or immaterial) of 'the past' and interpreting and valorising them through contemporary lenses. Thus, in this approach, the scholar's primary concern is to study how the past is being used (as heritage) in the present. Whilst this remains an important analytical approach, this article's search for an account of the slow ruination of the Führerbunker seeks to show that the fate of the Führerbunker is ultimately more than the sum of heritage debates and interpretations alone: for the persistence of that ruin is also a function of its resistant materiality, its political potency and wider urban contingencies.

This article's concern is therefore to account for the evolving life-course of the Führerbunker since 1945, accounting for its survival (of sorts) within an urban landscape otherwise subjected to comprehensive waves of, near total, urban erasure and renewal. The analysis will show the significance of the interplay of the Führerbunker's resistant material properties (i.e. the obstinacy of its subterranean reinforced concrete), its ascribed affective and atmospheric properties and the shifting politico-cultural intensities of remembering/ forgetting targeted at the bunker-ruin site across the last 70 years.

Attitudes towards any structure (and the action, forbearance, care and/or neglect that they engender) all have an influence over its rate of decay, and whether expressed as the anxious ruin-eradicating attentiveness of 'ruinphobia' (the ability of certain ruins to haunt urban managers, and wider publics, because of the feared disordering symbolic contagion that they represent (Bennett 2017b) and for which the Führerbunker presents an extreme-case exemplar) or in terms 
of instincts towards heritage revalorisation and potential conservation and curation.

In this regard the case study will show that despite its physical near-obliteration the Führerbunker remains extant - in that its notoriety appears to exceed its materiality. Thus to account for the persistence of the Führerbunker the analysis must necessarily consider not just the material decay aspect of ruination, but also acknowledge the parallel (and, at this exceptional site at least, seemingly slower) playing out of a semantic decay, by which the potency Führerbunker as a politically toxic symbol and/or 'difficult heritage' (Macdonald 2009) has - if not faded away - then at least modulated over time.

This article's focus is upon examining the Führerbunker's recent past, and it will largely present the Führerbunker ruins as a revenant, wound-like agent periodically resurfacing to trouble German memory and the contemporary ordering of the Berlin. No discussion is attempted of the Führerbunker's potential future rehabilitation as a more semantically open-ended, leisure and entertainment commodity. This is due to pressures of space in this article, and its desire to avoid dwelling on the theme of contemporary ruin/bunker re-appropriation to an extent that might drown-out other - less commonly heard - lines of enquiry.

Clearly the Führerbunker's semantic decay is still far from complete - it still has resonance, here witness the proliferation of 3D virtual reconstructions of the Führerbunker across the internet and movies. But as the Nazi era reaches the threshold of 'living memory' a less didactic framing of the Führerbunker's notoriety (and less fear of its ascribed infective power) might emerge in due course.

There is scope for further work to be done to understand the situation of the Führerbunker in the present-day, and also to further characterise the dynamics of semantic decay both for modern ruins generally and specifically as regards the Führerbunker (given that this present study has been able only to work with English language sources, and has approached its topic with the aim of con- textualising processes of demolition, ruination and urban renewal rather than examining the shifting figuration of the Führerbunker from the point of view of German memory/trauma studies).

Further investigation could, for instance, examine whether the increasing multivalence witnessed in recent re-valorisation and reengagement with the ruins of Cold War-era bunkers (see here the contributors to Bennett 2017a) might ever be replicated with their more unequivocally 'difficult heritage' cousins: Nazi bunkers. Such investigations could supplement this present study by investigating how (building on and updating the fieldwork of Till 2005, Jordan 2006, Macdonald 2009 and van der Hoorn 2009) the Führerbunker is now being 'used' by Berliners and tourists within practices of national and individual identity, and establish whether it is now becoming (or indeed could ever become) a ruin-place or ruin-image to be 'safely' experienced via the 'terror as sublime' aesthetic accessed in contemporary 'dark tourism' practices (Lennon \& Foley 2000), or furthermore, and ultimately, consumed as 'simply' another touristic stopping point on Berlin's heritage trail (noting here - as a first step in this journey - that Berlin's municipal authorities permitted the installation of a tourist information board at the otherwise nondescript site in 2006).

Having outlined the aims for, the context of and the limitations in its investigation, the article will now turn to presenting its case study account of the slow death of the Führerbunker.

\section{7-88: demolishing the Führerbunker}

In 1987 Robert Conrad, a young East German photographer risked his liberty by disguising himself as a construction worker and taking clandestine photographs of groundworks that were preparing a characterless central Berlin waste ground site for an unremarkable seeming urban regeneration: the erection of a new Plattenbau apartment block. But what had 
attracted Conrad's attention to this site was truly exceptional for, a few months earlier from the vantage point of a seat on a passing bus, he had glimpsed over the construction site's fence a: "completely insane landscape with enormous concrete ruins that had [lain] buried for decades protruding out of the ground" (quoted in Gunkel 2013: n.p.). What Conrad had witnessed was a major project to excavate Hitler's now-flooded bunker complex and, after dewatering it, to laboriously grub out its obstinate concrete elements, slab by slab. Formed in two levels, the works saw the remains of the upper Vorbunker torn out, and the massive roof of the offset deeper Führerbunker then broken up and collapsed into the rooms below. The resulting ruins were then filled with rubble, sand and gravel and covered over to form a nondescript carpark.

But this was not the first attempt to destroy the Führerbunker. The destruction of the Führerbunker has played out slowly over time through a mix of natural and human processes, and indeed the bunker has never quite fully died. In now turning to examine the earlier demolition attempts, and their shortcomings, the article will explore the intertwined factors shaping the slow-death of this 'difficult heritage'. Here, a heterogeneous mix of factors ranging from the physical resistance of reinforced concrete, groundwater penetration, the evolving politics of memory in Berlin, changing urban aesthetics and the vagaries of real estate have all had their role to play in both explaining the survival of the abandoned subterranean bunker for the first 43 years of its post-war life, and also its persistence as a haunting 'ruin' site since 1987-88.

\section{5-1986: The earlier postwar attempts to defeat the Führerbunker}

The first human destruction directed against the Führerbunker was Allied air raids in the closing months of the war, but these achieved no appreciable effect upon the underground bunker. Then came the Red Army's artillery assault on the 16th April 1945, as the prelude to its ground assault upon the city, with over 1 million shells fired at Berlin in one day. This caused extensive surface damage across the government district but also left the Führerbunker unscathed. The bunker held firm, because that was what it (and its 16 layers of reinforced concrete) had been built for: to resist attempts at its destruction. The bunker structure also survived the fires lit inside it by fleeing Nazis and subsequent looting by the Red Army units who took possession of it in in early May. Whilst above ground the government district lay in ruins, the Führerbunker remained substantively intact, and after German surrender on 7th May it became a regular stopping point in the victors' ruin-gazing tours of the conquered city, with Winston Churchill visiting on 1st July. Press photographs from that summer show U.S. and Red Army soldiers toying with Hitler's now abandoned possessions as they lay disordered within the Führerbunker's small, slowly flooding, cell-like rooms. This was the symbolic violence of the victor, acted out for the world to see: a more subtle version of the widespread, and more violent, sacking of the vanquished Nazi capital.

The bunker remained open to access until 1947 when the Red Army blew up the entrance, the ventilation shafts, collapsed some interior walls and caused the bunker's four metre thick roof to drop $40 \mathrm{~cm}$ - but the rest of the subterranean structure held firm. Meanwhile, above ground, the ruins of the Reich Chancellery were systematically razed to the ground and its marble salvaged for use in the construction of the Soviet war memorial in Treptower Park.

Set in the context of Berlin's post-war ruinscape a more expansive destruction (of the type seen in 1987-88) was simply unfeasible in 1947 due to a combination of the bunker's material resistance and pressing distractions elsewhere. Above ground lay $75,000,000 \mathrm{~m}^{3}$ of rubble and uninhabitable ruins that needed to be cleared to make the city liveable. Observing the scale of destruction Air Marshall Sir Arthur Tedder had sug- 
gested that Berlin neither could nor should ever be rebuilt and that instead "the ruins of Berlin should be preserved as a modern Babylon or Carthage - as a memorial to Prussian militarism and the Nazi regime" (quoted in Ladd 1997: 174). But in the prevailing humanitarian (and geo-political) context this was never going to be viable and in the aftermath of the war attention, energy and available resources turned to reconstruction, and to finding a non-Nazi future for Germany. Accordingly, Berlin was rebuilt, but slowly, falteringly and in a geopolitically bifurcated manner (until 1989 at least) that at times followed its own strange local logics of renewal and ruination, an urban clearance which entailed the demolition of thousands of ruined buildings and the burial of their foundations, cellars and shelters (and the recent past to which they might testify) beneath millions of tonnes of heaped rubble (Anderson 2017).

At the heart of the GDR's sense of communist futurity lay an assertion that that future could only be built upon foundations purged of Nazi contamination (Stangl 2018), for the East Germany state (est. 1949) styled itself as a bastion of antifascist resistance. The state's first leader, Walter Ulbricht declared in 1951 that "the men and women of the new Germany are clearing away the ruins of the old imperial Germany. From the ruins of the old Germany a new one arises" (quoted in Ladd 1997: 174) and the following year the GDR made its own first attempt at (re) demolition, works that saw removal of the Vorbunker's roof, the infilling of its voids and the subsequent grassing over of the site. But, despite this avowed denazification intent, the lower level Führerbunker remained substantively intact (albeit entombed by waste from the upper bunker and inaccessible until the excavation that Conrad witnessed in 1987). Ultimately, pragmatism lurked beneath Ulbricht's lofty tabula rasa aspirations, and in the end, whilst some iconic Naziera buildings in the governmental district were destroyed, others were quietly stripped of their Nazi symbols and repurposed to suit pressing post-war needs.
As we have seen the motivation behind the initial attempts at post-war destruction was that of the symbolic violence of conquest. As declared in the opening scenes of a July 1945 Pathé newsreel, as the camera sweeps the ruinscape: "the pompous buildings have paid the price of Hitler's crazy dream of conquering the world for Germany" (Pathé 1945). Here, a symbolic link is created between the (human) enemy and their key buildings - suggesting a need for the buildings themselves to be punished for the crimes that they have enabled, a phenomenon that stretches back to Roman times, but finds its more recent echo in the ritual demolition of dwellings in which notorious murders have occurred. Here, as Sniekers \& Reijnders (2011) note, is an attempt to detoxify a place through its physical destruction. But as their study shows, enforcing authorities are inconsistent in how rigorously they apply this sanction, and other factors often intrude to distract or preclude punitive demolition, even of the most heinous places.

Notably, misinformation and myth can have a role to play in fostering inaction or incompletion, perhaps fuelled by cultures of denial. Van der Hoorn (2009) finds evidence of this in Vienna, where the city's stillstanding Nazi flak towers are widely believed to be indestructible, even though most of Berlin's equivalent structures were successfully blown up shortly after the war. Meanwhile invisible, subterranean structures like the Führerbunker invite additional confusion around whether or not they have already been eliminated. As Till (2005) notes this proved to be the case with a Gestapo building excavated by West German activists from 1987, whose dig revealed the site's foundations and cellars despite confident assurances having been given to them by municipal officials that the site's postwar demolition had included a thorough and complete erasure of all subterranean features.

Even in a less febrile environment than post-war Berlin, demolition and rubble clearance is a practice equated with cornercutting and one characterised by limited 
paperwork, and even less formal discourse. Construction industry publications (Pledger 1977; Byles 2005) present demolition as an unsophisticated - almost unthought - process, in which the temptation is to keep cost and effort to a minimum. They point out that demolition can be improvised, unpredictable, expensive and/or unrewarding (in terms of salvage). Furthermore, the grubbing out of concrete foundations is often the most expensive part of demolition (Diven \& Shaurette 2010), and if the building itself lies wholly or partly underground (and/or is made of reinforced concrete) then its demolition will be a very difficult and expensive job. Van der Hoorn (2009) notes that one prompt in the calculus of demolition (rather than leaving a building in ruin) will be whether there is a use for the materials which the structure is made of. But Berlin was already very well served by supplies of rubble, and the Führerbunker held no marble or other valuable matter to incentivise its disassembly.

Reuse of the building or the site upon which it sits is another spur to its eradication, but following the 1952 demolition attempt, the Führerbunker thereafter found itself in a deadly backwater, a space in which new development was increasingly unlikely to prompt another attempt at erasure of the subterranean ruins, no matter how loathed they might be. The deadly backwater was the death strip created in service of the Berlin Wall. Here, from 1961 until 1989 the buried remains of the Führerbunker lay within an area cleared by the GDR and thereafter populated only by rabbits, ditches, paths, walls, security lights, barbed wire, electric fences, guard towers, spring guns, mine fields and tank traps. This was an intentional wasteland in the centre of the city, caused by two countries turning away from each other, a deadly desolation of 17 acres stretching from the Brandenburg Gate to Potzdamer Platz. Here time stood still for the Führerbunker until in 1987 the exigencies of the GDR's apartment building campaign brought development to the fringe of the death strip, and as Conrad witnessed, the Führerbunker then experienced a further wave of intentional destruction.

But despite Conrad's impression, the 1987-88 demolition works were not entirely secret. The GDR received enquiries from the Western media and, until overwhelmed by the attention, provided journalists with access to the site (Ramsey 1988). The East German goal of full denazification of this ruin remained evident in the response given by East Berlin building chief Ehrhardt Gisske, who declared to Reuters: "we are blowing everything up, every last bit will be detonated so no keepsake remains" (Reuters 1988: n.p.). But once again, this fantasy of obliteration did not come to pass, the bunker structure was further disassembled by the demolition works, but these works left many very large 'bits' of the bunker in existence, buried where they fell within the bunker's original structural footprint. Thus the Führerbunker had suffered substantial disordering through the 1987-88 works, but it remained extant as an invisible subterranean ruin-pile.

Then suddenly, and most unexpectedly, the Berlin Wall fell and in the early 1990s, and post-reunification urban renewal saw this backwater zone transformed into Europe's largest building site. And in that new era, and amidst changed attitudes to how to deal with the Nazi past, for a time the Führerbunker hovered close to - but never quite attained - resurrection as a monument -of-sorts.

\section{Post 1989: the Führerbunker as contaminant, rubble and/or countermonument}

Developments in German memorial culture since the 1970s increased the prospects for the remains (real or imagined) of the Führerbunker finding a new use, as a negative monument (a place of moral warning: a Mah$n m a /)$, a place in which the history of the site and the affective-material qualities of confined, subterranean structures could be put to work. The 1970s saw the emergence of a more pluralist, bottom-up approach 
to public- and urban- memory, first in West Berlin and then after 1989 in the East. In the 1970s West Germany turned to confront the Nazi past that it had seemingly so quickly forgotten in the aftermath of the war, initially with a focus upon memorialising victims (principally, but not exclusively, the Holocaust) and thereafter with a desire to memorialise sites of perpetrators - as a form of confrontation: via "brazen, painfully self-conscious memorial spaces conceived to challenge the very premises of their being"(Young 1993: 27).

In considering how the buried rubble-ruins of the Führerbunker came to be considered as a potential part of the burgeoning memorial culture of the 'new Berlin' we must first note the cultural awkwardness of the site and its material remains within German culture and polity, as an extreme case of 'ruinphobia' (Bennett 2017b). Time and again officials have worried that any official signification of (or access to) these 'ruins' might encourage Neo-Nazis to treat the site and its remains as a shrine to Hitler. The site was therefore seen as afflicted by a moral contamination which must be contained lest that contagion otherwise escape, and that that contamination was heightened by the connotations of 'bunker' as a place-form.

Bunkers have been figured by Beck (2011) as ambiguous structures, which contemporary culture has struggled to assimilate, due to their embodiment of violence and their ambiguous womb/tomb dichotomy. They also embody culturally encoded 'underworld' myths and present certain temporally disruptive 'time capsule'. For Virilio (1994) bunkers have atavistic connotations, working upon our perception in primal ways and psychoanalyst Carl Jung specifically regarded the Führerbunker as "a dark reflection of a universal symbol in the collective consciousness of our culture" (quoted in O'Donnell 1979: xi).

This anxiety about the Führerbunker is further amplified by its convergence with the Nazi's own belief in the power of the ruinous remains to transmit the Third Reich's greatness for 1,000 years. Hitler's architect, and the theorist of 'ruin value', Albert Speer how- ever did not regard the ferro-concrete of its bunkers as the stuff of posterity, it was the grand, stone fronted public buildings that were to endure, not the form-follows-function structures of its military fortifications. And yet - as the case of the Führerbunker shows - it is actually the bomb proof bunkers that have survived. In the face of this hidden survival, the managers of Berlin's urban realm worry that that these lurking subterranean remains might leech Nazism, and its related dark affects, into contemporary Berlin if given any attention.

A recent 'materialist' turn in cultural theory has seen the ascription of an affective vibrancy (and agency of sorts) to customarily 'dumb brute' matter. Bartolini (2015) has recently considered the limits of this ascribed potency in her analysis of the staging of an artist installation within an abandoned fascist era underground bunker in Rome. In Bartolini's analysis the artists' installation had failed to activate the bunker-space, such that it could operate productively upon its visitors as a confrontation. Bartolini argued, persuasively, that the building materials that compose the bunker are insufficient of themselves to transmit a historical sense of the bunker as a former geo-political nodal point. As she put it, "a concrete container located underground is not equivalent to identifying the structure as 'Mussolini's bunker'" (2015: 207).

Thus in Bartolini's view a bunker (or its remains) cannot be left to simply 'speak for itself', as to be more than a concrete container, a bunker needs to be culturally activated by curators and visitors, something which might have been achieved in the Rome bunker if the visitors to it could have been more actively engaged in the process of exploration and memory-making there (rather than just being shown there the artists' work and their own interpretation of the place and its traces of fascism and war). This 'active museum' philosophy reflects the founding principles of the activists who established the Topography of Terror memorial site, close to the Führerbunker (but in West Berlin) 
in 1987. At the time that Conrad was watching the grubbing out of the Führerbunker in order to bury it, on the other side of the Berlin Wall these activist were leading public excavations of the foundations and cellars of the former Gestapo HQ. The activists established a processional curation of the site which incorporated a descent into the excavated cellars as a destination for confrontation with Germany's Nazi past. At this site the aim - anchored in the processual materiality of excavation - was to keep a raw wound within the heart of Berlin. Gentrification of the surrounding area following reunification has caused that site to lose some of its rawness, but excavation and confrontation co-opting the visceral, affective qualities of exposed subterranean spaces remains key to the site's rationale and the idea that materiality plus memory can have powerful "pedagogic power" (Jordan 2006: 44).

Young (1993) has noted the rise of countermonuments - sites that seek like Mahnmal to unsettle but which also aim to avoid redemption or semantic closure. This trend is apparently echoed in the evolution of Berlin's urban aesthetics, wherein Göbel (2015) and Sandler (2016) have pointed to an ingrained resistance towards cleansing or finishing buildings in the city, as though a provocative roughness contributes to their ability to resist the neat closure or resolution of history. In particular, Göbel has pointed to the significance of ruin atmospheres within this process of intentionally uncomforted dwelling. Meanwhile, the unhomely (unheimlicht - uncanny) atmospheric potentiality of abandoned bunkers has been exploited by sound and installation artists like Sandys (2017), using the particular properties of their confined spaces through which to provoke unsettling, embodied affects in their visitors in order to re-animate an abandoned subterranean bunkers' "intimate intensities" (Adey 2013: 53), through intentional aesthetic, atmospheric design. In Berlin these trends converge in the motif of viewable but inaccessible confined grey void spaces, which were incorporated to arresting effect in Daniel
Libeskind's design for his Jewish Museum (opened in Berlin in 2001).

It is not known whether the 1987-88 demolition works left any voids within the subterranean rubble-pile of the Führerbunker, but given its potent symbolic and phenomenological properties, and in the wake of these trends in Berlin's urban aesthetics and memorial culture, it is perhaps not surprising that the 1990s saw intermittent awkward contemplation of the memorial potential of the Führerbunker's imagined void spaces, most notably that in 1994 Harald Szeemann's recommendation that the Führerbunker site be incorporated into the proposed Memorial to the Murdered Jews of Europe formed part of the instructions issued to competitors in the first design contest for that memorial. As Till (2005) reports, Szeemann envisaged a visitor accessing, confronting and processionally overcoming the Führerbunker. Visitors would enter and walk through "an underground landscape of memory" (2005: 176) - confronting the past as they moved between different rooms (extant or reconstructed) along a path of redemption. The Szeemann design rationale stated: "buried deep in the earth were bunkers in which the perpetrators hid in the final hour before the destruction they had wreaked on others struck back at them and in which Hitler's mania ended in suicide. Reference should be made to this combination of hubris, destruction and self-destruction" (quoted in Till 2005: 176). Additionally, Szeemann said the memorial should "violate the earth" and "sink into it like memory". However, there was considerable opposition to the idea of connecting the memorial to the site of the Führerbunker, both from Jewish groups and local government - who objected to any memorialisation or heritage designation on the basis that the Führerbunker lay partly beneath the apartment buildings and partly because the "bunkers are neither architecturally nor materially in any way perceptible" (quoted in Jordan 2006: 122). Instead the Jewish memorial (now to be designed by Peter Eisenman's following a fresh design competition in 1998) would be built elsewhere upon 
the former death strip. But even the new site was not free of Nazi moral contamination, as it was close to the former site of Joseph Goebbels' town house, and even closer to its underground bunker. Once again there was suggestion that there might be confrontational value in incorporating a Nazi bunker in some way into the memorial, but this suggestion was also rejected and the Goebbels' bunker remained sealed. The monument does, however, feature a $800 \mathrm{~m}^{2}$ bunker-like subterranean information centre beneath its field of 2,700 concrete stelae.

The discovery of the Goebbels bunker shows the former death strip as revenant ground, where the past unexpectedly surfaces to interfere with the plans of the present. As Ladd notes: "planners and developers at work in the new Berlin come to grief again and again when they try to treat the city's streets and buildings and lots as mere real estate" (1997: 3). Coming to terms with the inherited realities of the ground conditions of any 'brownfield' site is a complex process of familiarisation (Bennett \& Crawley Jackson 2017) and Moshenska (2010) has shown that when the relics of conflict are encountered during development works, this causes a jarring effect in which the past suddenly intrudes, and whether in the form of unexploded bombs, the remains of combatants or the subterranean structures that proliferate in wartime and for which accurate plans showing location and extent do not always exist. For Moshenska this jarring is, itself, a form of countermonumentality.

Goebbels' bunker was not the only subterranean structure to unexpectedly surface during redevelopment of the death strip. In the summer of 1990, as part of preparation for a rock concert to celebrate the fall of the Wall, a security sweep found the roof of a bunker, one of an estimated 20 or so bunkers built and interconnected in the vicinity of the Führerbunker. The bunker was found to be a facility for Hitler's SS guards and drivers' unit. On opening it the bunker was revealed to be a Nazi time-capsule: untouched since 1945, replete with weapons, silverware and eight kitschy wall paintings showing SS soldiers fighting to protect women and Germany. This discovery caused alarm and immediate calls for the bunker's destruction. It was quickly resealed, although in 1992 Alfred Kernd'l, head of the municipal archaeology office was allowed to reopen and inventory it. Kernd'l's subsequent call for preservation of this place met fierce opposition - including from some groups otherwise in favour of confronting the past - amidst fear of creating a Neo-Nazi shrine. Kernd'l countered that destruction of this bunker would signal significance (and fear of potency) to the Neo-Nazis, by ascribing a latent power to the remains that they did not deserve. Instead, for Kernd'I the bunker exposed the banality of evil - the implication of low ranks and the arrogance and sentimentality at the heart of the Nazi regime. In the end the Berlin Senate decided against opening the bunker to the public. It suggested that the wall paintings could be moved to the German Historical Museum - but they wanted nothing to do with them. Thereafter the bunker was sealed up again. It, like many of the other bunkers, now lies buried beneath the government buildings constructed upon the death strip towards the end of the 1990s (ownership of the strip having been parcelled out to the German federal states).

A particular problem with the drivers' bunker was that it projected a warlike, defiant Nazism - something quite different from the Hitlers'-last-days abjection commonly ascribed to the Führerbunker. Like tombs, bunkers pose difficulties and opportunities in their ease at acting like a self-archiving time-capsule. They work well to protect their contents, and the times and ideas that they embody without the need for human involvement. Therefore, discovery of them throws one world into another, with an authenticity that may be too much to bear, because the story of Berlin's Nazi underground is not just one of impotence, downfall, and civilian shelter (in an improvised subterranean world of cellar dwelling), it was also stories of wardirecting and extermination-coordination proudly acted out below ground. 
Oddly, some Nazi bunkers for which the main narratives are war-directing and extermination-coordination have, it seems, been readily converted into post-war military use and/or museums, like the Wolf's Lair, and command bunkers at Zossen, Marienthal, and along the Atlantic Wall. But seemingly this museumification would be too much to bear in the still charged atmosphere of central Berlin. As Jordan notes it appears that most of the parties involved in decision making about the central Berlin bunkers still share a belief in "the power of authentic location and the moral content of this physical place, implying a belief in a kind of material transmission of evil" (2006: 188). During the debate about the drivers' bunkers activists from the Topography of Terror suggested that access could be arranged by tours led by guides trained in anti-fascist education in order to ensure that the fine line between a beneficial and confrontational exposure to the Nazi past did not tip over into an advert for Nazism. The bunker thus presented as a complex and potent moral object, with a pedagogic power that could contaminate contemporary polities (and sensibilities) if not carefully curated by inoculated specialists.

\section{Conclusion: the Führerbunker as material and immaterial ruin}

As Jordan (2006) has noted, not all seemingly strong candidates for memorialisation become memorials. These early 1990s encounters with the Chancellery's satellite bunkers emphasised to all concerned that some things may still be too difficult to surface. And indeed, that even the act of destruction would involve a temporary surfacing (as Conrad witnessed in 1987-88) that could risk a release of moral contamination. Unsurprisingly therefore the older West German postwar reflex of 'letting the grass grow' over difficult heritage resurfaced.

It is unfair to use the complex moral charge of the Führerbunker and its satellites to directly challenge Bartolini's analysis of her, far less morally loaded, fascist bunker in Rome.
However, the experience in central Berlin does throw up a challenge to Bartolini's suggestion that a sealed off subterranean bunker is not a 'palimpsest' (Huyssen 2003), because "the bunker is not a trace or a shadow as it is present and also part of the foundation of an office building, and it does not haunt the landscape since, as a shelter, it was never meant to be seen in the first place." (2015: 206). This statement seems too fixated on the ocular, because the visibility of the bunker is not the only register by which it persists or acts upon the surface (or the present). Within central Berlin the 'invisible' ruins of Nazi bunkers resonate as symbols which appear too authentic to encounter, even within the reflexive, confrontational formulae of countermonumentality.

Bartolini also appears to equate existence with human accessibility. The Führerbunker has been crushed and compacted by successive demolition projects. There may be isolated voids (although they are probably flooded if they exist). There may be traces of the structure that could be perceived by excavation, ground penetrating radar or endoscopy, but what would be viewed would be very much a non-human terrain, no human could dwell there. However, a ruin is not just matter, it is a place at which matter has been signified in a particular way. And for the Führerbunker the narrative that feeds that enduring signification remains strong. Ever since a young British army intelligence officer, Trevor-Roper (1995) published the results of his investigation into Hitler's last days in 1947, the Führerbunker has resonated through AngloAmerican culture, feeding waves of cultural production and dark tourism alike. As van der Hoorn (2009) notes, some undesired places are so undesired that they are needed - because they provide part of our symbolic universe (and whether moral, aesthetic or otherwise). Thus, ruins of an extremely destroyed condition can still signify even if invisible and intentionally ignored by officialdom, snubbed by a strategy of "profanation" (Macdonald 2009: 88) that seeks to symbolically deny significance to the site through the mundanity of its overlying carparks, roadways and 
municipal buildings. Furthermore, monumentalisation does not just exist in the physical world - the Führerbunker has a potent symbolic existence via myriad maps, models and photographs (Bennett 2011). Suppression of its physical site may be a necessary tactic for ensuring that an overdose of pedagogic power does not occur, but blanking the physical presence of the (uninhabitable) remains of the Führerbunker is not the same thing as the eradication of representations of the Führerbunker, and in the absence of directed narratives more speculative, mythic readings of the bland site will continue to circulate, and whether for good or ill, as one blogger reflects at the site (Pearson 2011):

\section{References}

AdEy P., 2013. Securing the volume/volume. Comments on Stuart Elden's plenary paper 'Secure the volume'. Political Geography, vol. 34, pp. 52-54.

Anderson B., 2017. Buried City, Unearthing Teufelsberg. Berlin and its geography of forgetting. London: Routledge.

BARTOLINI N., 2015. The politics of vibrant matter. Consistency, containment and the concrete of Mussolini's bunker. Journal of Material Culture, vol. 20, no. 2, pp. 191-210.

BECK J., 2011. Concrete ambivalence. Inside the bunker complex. Cultural Politics, vol. 7, no. 1, pp. 79-102.

Bennett L., 2011. The Bunker: Metaphor, materiality \& management. Culture and Organization, vol. 17, no. 2, pp. 155-173.

Bennett L. (ed.), 2017a. In the ruins of the Cold War bunker. Affect, materiality and meaning making. London: Rowman \& Littlefield International.

BenNetT L., 2017b. Forcing the empties back to work? Ruinphobia and the bluntness of law and policy [in:] J. Henneberry (ed.) Transience and permanence in urban development: Real estate issues, Hoboken, NJ: Wiley, pp. 17-30.

Bennett L., Crawley Jackson A., 2017. Making common ground with strangers at Furnace
"The ground is uneven, the grass shabby, there are a few stones littered around, and you can pick up one and ask whether it was once part of the great ensemble of buildings meant to protect the Führer. The imagination runs wild with speculation, the absence of evidence invites this. Where underground are the cells, which contained communication switchboards, generators, ventilators, bedrooms, water tanks and wine cellars? I half imagine a whole crew of Nazis, underground, still waiting, for the right moment to emerge, like a scene from a Kusturica film. There is a silence about this place that provokes fantasy. Meanwhile, there is no official impetus to excavate, or even to memorialise further."

Park. Social \& Cultural Geography, vol. 18, no. 1, pp. 92-108.

BYLES J., 2005. Rubble: Unearthing the history of demolition. New York: Harmony Book.

CAIRNS S., JACOBS J.A., 2014. Buildings must die: A perverse view of architecture. London: The MIT Press.

DeSilvey C., Edensor T., 2013. Reckoning with ruins. Progress in Human Geography, vol. 37, no. 4, pp. 465-485.

Diven R.J., Shaurette M., 2010. Demolition: Practices, technology and management. West Lafayette, IN: Purdue University Press.

ELDEN S., 2013. Secure the volume: Vertical geopolitics and the depth of power. Political Geography, vol. 34, pp. 35-51.

GÖBEL H.K., 2015. The reuse of urban ruins: Atmospheric inquiries of the city. London: Routledge.

GUNKEL C., 2013. Secret shots of Hitler's bunker. Spiegel Online (International), 4 June http:// www.spiegel.de/international/germany/secretphotographs-of-hitler-bunker-in-berlin-by-robert-conrad-a-903750.html [23 January 2018].

HarRISOn R., 2013. Heritage: Critical approaches. London: Routledge.

HuYsSEN A., 2003. Present pasts: Urban palimpsests and the politics of memory. Stanford: Stanford University Press. 
JORDAN J.A., 2006. Structures of memory: Understanding urban change in Berlin and beyond. Stanford, CA: Stanford University Press.

KLINKE I., 2018. Cryptic concrete: A subterranean journey into Cold War Germany. Chichester: Wiley Blackwell.

LADD B., 1997. The ghosts of Berlin: Confronting German history in the urban landscape. London: The University of Chicago Press.

LenNON J., Foley M., 2000. Dark tourism: The attraction of death and disaster. Andover: Cengage Learning.

Macdonald S., 2009. Difficult heritage: Negotiating the Nazi past in Nuremberg and beyond. London: Routledge.

MoshensKa G., 2010. Charred churches or iron harvests?: Counter-monumentality and the commemoration of the London blitz. Journal of Social Archaeology, vol. 10, no. 1, pp. 5-27.

O'DonnelL J.P., 1979. The Berlin bunker. London: J.M. Dent \& Sons Ltd.

Pathé, 1945. British enter Berlin. Newsreel film. London: British Pathé. Accessed at: https:// www.youtube.com/watch? $v=\mathrm{C} 0$ hq $8 \times B \operatorname{PrZA}$ [28 March 2018].

PeArson J., 2011. Forcing Hitler underground. The Fuhrer bunker. A blogpost at: http://needleberlin.com/2011/06/19/hitlers-bunker-fearing-thepast/ [28 March 2018].

Pledger D.M., 1977. A complete guide to demolition. Lancaster: Construction Press.

RAMSEY W.G., 1988. The Reichs Chancellery and the Berlin Bunker then and now. After The Battle, vol. 61.

ReUters, 1988. E. Berlin to raze Hitler's suicide bunker. Los Angeles Times, 1 June.
SAndler D., 2016. Counterpreservation: Architectural decay in Berlin since 1989. Ithaca, NY: Cornell University Press.

SANDYS K., 2017. Sublime concrete: The fantasy bunker, explored [in:] L. Bennett (ed.), In the ruins of the cold war bunker. Affect, materiality and meaning-making. London: Rowman \& Littlefield International, pp. 57-74.

SMITH L., 2006. Uses of heritage. London: Routledge.

Sneikers M., ReIJnders S., 2011. Imprisoned by Dutroux: An ethnography of guilty houses in Belgium. Northern Lights: Film and Media Studies Yearbook, vol. 9, no. 1, pp. 27-44.

Stangl P., 2018. Risen from ruins: The cultural politics of rebuilding East Berlin. Stanford CA: Stanford University Press.

TILL K.E., 2005. The new Berlin: Memory, politics, place. Minneapolis: University of Minnesota Press.

Trevor-Roper H., 1995. The last days of Hitler. London: Papermac.

Tzalmona R., 2011. Traces of the Atlantikwall or the ruins that were built to last.... Third Text. Critical Perspectives on Contemporary Art \& Culture, vol. 25, no. 6, pp. 775-786.

VAN der HOORN M., 2009. Indispensable eyesores: An anthropology of undesired buildings. Oxford: Berghahn Books.

VIRILIO P., 1994. Bunker archeology. London: Princeton Architectural Press.

Young J.E., 1993. The texture of memory: Holocaust memorials and meaning. London: Yale University Press. 